\section{How does spatial variability of climate affect catchment streamflow predictions?,} \\ Patil, S.D.; Wigington, P.J.; Leibowitz, S.G.; Sproles, E.A.; Comeleo, R.L.

\section{Journal of Hydrology} \\ DOI: \\ 10.1016/j.jhydrol.2014.05.017 \\ Published: 17/05/2014
}

Peer reviewed version

Cyswllt i'r cyhoeddiad / Link to publication

Dyfyniad o'r fersiwn a gyhoeddwyd / Citation for published version (APA):

Patil, S. D., Wigington, P. J., Leibowitz, S. G., Sproles, E. A., \& Comeleo, R. L. (2014). How does spatial variability of climate affect catchment streamflow predictions?, Journal of Hydrology, 517, 135-145. https://doi.org/10.1016/j.jhydrol.2014.05.017

\footnotetext{
Hawliau Cyffredinol / General rights

Copyright and moral rights for the publications made accessible in the public portal are retained by the authors and/or other copyright owners and it is a condition of accessing publications that users recognise and abide by the legal requirements associated with these rights.

- Users may download and print one copy of any publication from the public portal for the purpose of private study or research.

- You may not further distribute the material or use it for any profit-making activity or commercial gain

- You may freely distribute the URL identifying the publication in the public portal ?

Take down policy

Author's post-print must be released with a Creative Commons Attribution Non-Commercial No Derivatives License

Take down policy

If you believe that this document breaches copyright please contact us providing details, and we will remove access to the work immediately and investigate your claim.
} 
NOTICE: This is the author's version of a work that was peer reviewed and accepted for publication in the Journal of Hydrology. Changes resulting from the publishing process, such as editing, corrections, structural formatting, and other quality control mechanisms may not be reflected in this document. A definitive version was subsequently published in JOURNAL OF HYDROLOGY, VOL 517, DOI http://dx.doi.org/10.1016/j.jhydrol.2014.05.017

\section{How does spatial variability of climate affect catchment}

\section{streamflow predictions?}

Sopan D. Patil ${ }^{1,2}$, Parker J. Wigington Jr. ${ }^{3,4}$, Scott G. Leibowitz ${ }^{3}$, Eric A. Sproles ${ }^{1,5}$, Randy L. Comeleo $^{3}$

${ }^{1}$ ORISE, c/o U.S. Environmental Protection Agency,

200 SW $35^{\text {th }}$ St., Corvallis, OR 97333, USA

${ }^{2}$ School of Environment, Natural Resources and Geography,

Bangor University,

Deiniol Road, Bangor, LL57 2UW, United Kingdom

${ }^{3}$ Western Ecology Division,

National Health and Environmental Effects Research Laboratory,

U.S. Environmental Protection Agency,

200 SW $35^{\text {th }}$ St., Corvallis, OR 97333, USA 
${ }^{4}$ Retired

${ }^{5}$ Centro de Estudios Avanzados en Zonas Áridas

Universidad de La Serena

Raul Bitran s/n, La Serena, Chile

Submission to: Journal of Hydrology

Correspondence to: s.d.patil@bangor.ac.uk

\section{Highlights:}

1) We compare lumped and distributed hydrologic models at 41 catchments in northwest USA.

2) Distributed model performs better in catchments with low moisture homogeneity.

3) Spatial variability of precipitation phase is important in homogenous catchments. 


\section{Abstract}

2 Spatial variability of climate can negatively affect catchment streamflow predictions if it is not

3 explicitly accounted for in hydrologic models. In this paper, we examine the changes in

4 streamflow predictability when a hydrologic model is run with spatially variable (distributed)

5 meteorological inputs instead of spatially uniform (lumped) meteorological inputs. Both lumped

6 and distributed versions of the EXP-HYDRO model are implemented at 41 meso-scale (500 -

$75000 \mathrm{~km}^{2}$ ) catchments in the Pacific Northwest region of USA. We use two complementary

8 metrics of long-term spatial climate variability, moisture homogeneity index $\left(I_{M}\right)$ and

9 temperature variability index $\left(I_{T V}\right)$, to analyze the performance improvement with distributed

10 model. Results show that the distributed model performs better than the lumped model in 38 out

11 of 41 catchments, and noticeably better (>10\% improvement) in 13 catchments. Furthermore,

12 spatial variability of moisture distribution alone is insufficient to explain the observed patterns of

13 model performance improvement. For catchments with low moisture homogeneity $\left(I_{M}<80 \%\right)$,

$14 I_{M}$ is a better predictor of model performance improvement than $I_{T V}$; whereas for catchments

15 with high moisture homogeneity $\left(I_{M}>80 \%\right), I_{T V}$ is a better predictor of performance

16 improvement than $I_{M}$. Based on the results, we conclude that: (1) catchments that have low

17 homogeneity of moisture distribution are the obvious candidates for using spatially distributed

18 meteorological inputs, and (2) catchments with a homogeneous moisture distribution benefit

19 from spatially distributed meteorological inputs if they also have high spatial variability of

20 precipitation phase (rain vs. snow).

22 Keywords: Hydrologic model, climate variability, streamflow, catchment 


\section{Introduction}

24 Meteorological inputs such as precipitation, air temperature, and potential

25 evapotranspiration in spatially lumped hydrologic models consist of one-dimensional time series

26 data. These data are obtained either from a single meteorological station located within the

27 catchment [Segond et al., 2007; Vaze et al., 2011], from spatial interpolation of multiple

28 meteorological stations in the region [Arnaud et al., 2002; Chaubey et al., 1999; Tobin et al.,

29 2011], or from an areal mean of meteorological data grids that cover the catchment's drainage

30 area [Koren et al., 1999; Patil and Stieglitz, 2014]. An important assumption in these models is

31 that the one-dimensional inputs are uniformly distributed over the entire catchment. Numerous

32 studies have shown that the quality of meteorological data used has a direct influence on the

33 quality of modeled streamflow predictions [Andréassian et al., 2001; Bárdossy and Das, 2008;

34 Faurès et al., 1995; McMillan et al., 2011; Obled et al., 1994; Vaze et al., 2011]. Andréassian et

35 al. [2001] studied the impact of rain gage density on streamflow predictability at three

36 catchments in France and found that the performance of rainfall-runoff models was directly

37 proportional to the rain gage density used to generate the rainfall input. Oudin et al. [2006a]

38 studied the effect of random and systematic errors in climate input data on streamflow

39 predictions at 12 US catchments and found that random errors in rainfall series significantly

40 affect the model performance; however, systematic errors in potential evapotranspiration series

41 had greater impact on model performance than random errors. In Australia, Vaze et al. [2011]

42 observed improved performance in hydrologic models when rainfall estimates were obtained

43 from a gridded meteorological dataset compared to a single rain gage or a Thiessen weighted

44 average of multiple rain gages. 
Regardless of the data preparation technique, a spatially uniform representation of

46 meteorological inputs has the potential to introduce significant uncertainty in catchments with

47 high spatial variability of climate, and can negatively affect streamflow predictability [Bárdossy

48 and Das, 2008; Chaubey et al., 1999; Moulin et al., 2009; Shen et al., 2012]. Spatial variability

49 in rainfall can affect the estimation of hydrologic properties such as peak flow magnitude and

50 timing, stream flow volume, and soil moisture condition [Arnaud et al., 2002; Beven and

51 Hornberger, 1982; Krajewski et al., 1991; Nicótina et al., 2008; Tramblay et al., 2011]. On the

52 other hand, spatial variability in air temperature can affect the estimation of properties such as

53 snow cover extent, snow storage magnitude, and snowmelt timing [Jefferson, 2011; Leibowitz et

54 al., 2012; Nolin and Daly, 2006; Sproles et al., 2013]. Nonetheless, the degree to which spatial

55 variability of climate affects catchment streamflow predictions is not fully understood.

Hydrologic models that use spatially distributed meteorological data (henceforth referred

57 to as distributed models) are better equipped than those that use spatially uniform meteorological

58 data (henceforth referred to as lumped models) to handle the spatial variability of climate.

59 However, studies that have compared the lumped and distributed models provide a mixed picture

60 on the perceived advantage of distributed models. For instance, model comparisons using

61 theoretical approaches (e.g., virtual experiments) have typically been more favorable towards

62 distributed models [Andréassian et al., 2004; Krajewski et al., 1991; Wilson et al., 1979; Zhao et

63 al., 2013]. Andréassian et al. [2004] introduced the concept of chimera watersheds in which

64 multiple combinations of the data from real watersheds are used to create a large number of

65 virtual 'chimera' watersheds so that more heterogeneity can be obtained than is present in the

66 existing data. Using these chimera watersheds, Andréassian et al. [2004] showed that distributed

67 models provide much better simulation performance than lumped models. Zhao et al. [2013] 
68 performed virtual experiments on 60 catchments in southeast Australia by systematically varying

69 the spatial variability of rainfall in each catchment (while still preserving the total rainfall

70 volume). The authors concluded that "for a given rainfall total, ignoring spatial rainfall

71 variability will result in underestimation of the total streamflow volume and overestimation of

72 evapotranspiration". In contrast, studies that have used real catchment data show that in most

73 cases, only marginal improvements in streamflow predictions are obtained with distributed

74 models compared to lumped models [Boyle et al., 2001; Das et al., 2008; Refsgaard and

75 Knudsen, 1996; Vaze et al., 2011]. Reed et al. [2004] summarized multiple results from the

76 Distributed Model Intercomparison (DMIP) initiative and concluded that in most of the DMIP

77 catchments, lumped models performed equally well or even slightly better than the distributed

78 models. Similar results were shown by Khakbaz et al. [2012] in the newer DMIP 2 study. Thus,

79 in spite of numerous studies comparing lumped and distributed models, we still cannot fully

80 differentiate the types of catchments that will truly benefit from the use of distributed models in

81 order to achieve improved streamflow predictability.

82 In this paper, our goal is to better understand the climatic conditions of catchments for

83 which a distributed model does (or does not) provide better streamflow predictions than a

84 lumped model. Both lumped and distributed versions of the Exponential Bucket Hydrologic

85 Model (EXP-HYDRO) [Patil and Stieglitz, 2014] are applied at 41 meso-scale catchments (500

$86-5000 \mathrm{~km}^{2}$ ) in the Pacific Northwest region of USA. We begin with an a priori expectation

87 that, in the absence of any additional information, the distributed model will have the same

88 streamflow prediction capability as the lumped model at all catchments. For each catchment, we

89 then determine whether any improvement occurs with the use of the distributed model and

90 analyze this performance improvement within the context of long-term spatial climate variability 
91 in the catchment. We characterize the spatial climate variability in all catchments by using two

92 different metrics, viz., moisture homogeneity index and temperature variability index.

\section{Study Area and Data}

95 Our study area is in the Pacific Northwest (PNW) region of USA and covers the states of

96 Oregon, Washington, and Idaho (Figure 1). Within these three states, we select 41 catchments

97 that satisfy the following two criteria: (1) they belong to either the HCDN [Slack et al., 1993] or

98 GAGES [Falcone et al., 2010] database of the U.S. Geological Survey (USGS), and (2) their

99 drainage areas are within the 500 to $5000 \mathrm{~km}^{2}$ range. The selection from HCDN and GAGES

100 databases is done to ensure that the hydrologic regimes of the catchments are minimally

101 impacted by anthropogenic effects. The specified range limit of drainage areas is to ensure that

102 the catchments are large enough to detect spatial climate variability within them, but small

103 enough to ignore the delays in streamflow response due to channel network routing. The

104 drainage area of the catchments varies from $518 \mathrm{~km}^{2}$ to $4956 \mathrm{~km}^{2}$, with the median drainage area

105 of $865 \mathrm{~km}^{2}$. The mean annual precipitation in the catchments varies from $540 \mathrm{~mm}$ to $3615 \mathrm{~mm}$,

106 with the median value of $1251 \mathrm{~mm}$. Of the 41 chosen catchments, 20 are located in Oregon, 7

107 are located in Washington, and 14 are located in Idaho (see Figure 1).

108 Climate of the PNW region is highly influenced by large scale atmospheric circulation

109 patterns caused by the presence of Pacific Ocean to the west and the subsequent interaction of

110 these patterns with the Cascade and Rocky Mountain ranges [Salathé et al., 2008]. This

111 interaction creates a strong climate gradient in the west-to-east direction. The western parts of

112 the PNW, between the Pacific Ocean and the Cascade Mountains, experience high amounts of

113 rainfall and mild temperatures due to the maritime climate influence [Wigington et al., 2013]. 
114 The eastern parts, between the Cascade and Rocky Mountains, are much drier because of the

115 rain-shadow effect of the Cascade Mountains and experience more extreme intra-annual

116 temperature differences. Roughly two-thirds of the precipitation in the PNW occurs during the

117 colder October to March period, while most of the region typically experiences dry summers.

118 Annual precipitation amounts and temperature are further influenced by the long term climate

119 trends caused by the El Niño Southern Oscillation (ENSO) and the Pacific Decadal Oscillation

120 (PDO) [Brown and Kipfmueller, 2011; Cayan, 1996]. Due to high elevations of the Cascades

121 and the Rockies, a significant amount of precipitation (much of it snow) is captured in the

122 region's mountains. As a result, the hydrology of major rivers in this region (e.g., Columbia,

123 Snake, and Willamette) is dominated by snow accumulation in the winter season and snowmelt

124 in the spring season [Hamlet and Lettenmaier, 1999; Regonda et al., 2005; Safeeq et al., 2013].

125 We use the daily streamflow data from USGS stream gages that are located at the outlet

126 of all 41 catchments. The time-span of the streamflow and meteorological input data is 20 years,

127 ranging from water year 1971 to 1990 (i.e., $1^{\text {st }}$ October, 1970 to $30^{\text {th }}$ September 1990 ). Daily

128 data of the meteorological inputs (precipitation and air temperature) is obtained from the gridded

129 observed meteorological dataset developed by Maurer et al. [2002]. This dataset has the spatial

130 resolution of 0.125 degrees (about $100 \mathrm{~km}^{2}$ grid) and covers the entire continental United States.

131 Given that our smallest study catchment has a drainage area of $518 \mathrm{~km}^{2}$, the ratio of the

132 meteorological grid resolution to basin size is less than 0.2 for all catchments. The methods used

133 to obtain the lumped and distributed versions of precipitation and air temperature inputs from the

134 gridded dataset for each catchment are described in Section 3.2. Daily potential

135 evapotranspiration inputs (both lumped and distributed version) are calculated directly from the

136 daily air temperature data using Hamon's formula [Hamon, 1963]. For calculation of the two 
137 climate variability metrics at each catchment (see Section 3.3 for further details), we use the 30-

138 year (1971-2000) average values of precipitation, air temperature, and potential

139 evapotranspiration that are derived from the long-term data of Climate Source, Inc.

140 (http://www.climatesource.com/us/fact_sheets/fact_tmean_us_71b.html). This commercially

141 available data has a resolution of $400 \mathrm{~m}$ and covers the entire continental United States (see

142 Wigington et al. [2013] for details).

\section{Methods}

\section{$145 \quad 3.1 \quad H y d r o l o g i c$ model}

146 The EXP-HYDRO model was originally developed by Patil and Stieglitz [2014] as a

147 spatially lumped hydrologic model that operates at a daily time-step. In this paper, we have used 148 the original lumped version of the model as well as a modified version that explicitly accounts

149 for spatially distributed meteorological inputs (see section 3.2 for details). Below, we provide a 150 brief description of the model.

151 The EXP-HYDRO model conceptualizes a catchment as a bucket store that receives

152 water inputs in the form of liquid precipitation and snowmelt and has water outputs in the form

153 of evapotranspiration, subsurface runoff, and capacity-excess surface runoff (Figure 2). Daily

154 precipitation is first classified as either rainfall or snowfall, depending on the day's air

155 temperature. Snowfall accumulates separately into the snow accumulation bucket, whereas the

156 rainfall is input directly into the catchment bucket. Snowmelt from the snow accumulation

157 bucket is modeled using a thermal degree-day model, and the melt runoff generated is used as an

158 input to the catchment bucket. The amount of evapotranspiration in the catchment is calculated 159 as a fraction of potential evapotranspiration and depends on the ratio of actual water stored in the 
160 catchment bucket on the given day to the catchment bucket's storage capacity. Subsurface

161 runoff depends on the amount of water stored in the catchment bucket and is calculated using a

162 TOPMODEL [Beven and Kirkby, 1979] type exponential equation. Capacity-excess surface

163 runoff occurs once the catchment bucket is filled to its capacity and there is still some excess

164 amount of water from the rainfall and snowmelt inputs. Catchment streamflow is calculated as

165 the sum of subsurface runoff and capacity-excess surface runoff. Detailed description of the

166 mathematical formulas of this model can be found in Patil and Stieglitz [2014] and Patil et al. [in

167 press].

168 There are six free calibration parameters in the EXP-HYDRO model: $f, S_{\max }, Q_{\max }, D_{f}$,

$169 T_{\max }$, and $T_{\min }$. The parameter $f$ (unit: $1 / \mathrm{mm}$ ) controls the rate of decline in subsurface runoff

170 from the catchment bucket as its storage level fluctuates. $S_{\max }$ (unit: $\mathrm{mm}$ ) is the maximum

171 storage capacity of the catchment bucket. $Q_{\max }$ (unit: $\mathrm{mm} /$ day) is the maximum subsurface

172 runoff that occurs when the catchment bucket is full. $D_{f}$ (unit: $\mathrm{mm} /$ day $/{ }^{\circ} \mathrm{C}$ ) is the thermal

173 degree-day factor that controls the rate of snowmelt from the snow bucket. $T_{\max }$ (unit: ${ }^{\circ} \mathrm{C}$ ) is the

174 air temperature above which snow starts melting, whereas $T_{\min }$ (unit: ${ }^{\circ} \mathrm{C}$ ) is the air temperature

175 below which precipitation falls as snow. We calibrate these parameters for each catchment with

176 50,000 Monte Carlo simulations [Vaché and McDonnell, 2006]. Parameter ranges used for the

177 random sampling of all six parameters are the same as those in Patil and Stieglitz [2014].

178 Modeled streamflow values from the first year are used for model spin-up. From the remaining

17919 years of record, streamflow values of the first 9 years (water year 1972 to 1980) are used for

180 model calibration and those of the next 10 years (water year 1981 to 1990) are used for model

181 validation. Nash-Sutcliffe efficiency (NS) of square root transformed values of daily streamflow

182 (see Oudin et al. [2006b]) is used as the objective function for calibration: 


$$
N S=1-\frac{\sum_{i=1}^{n}\left(\sqrt{Q_{o b s, i}}-\sqrt{Q_{\text {pred }, i}}\right)^{2}}{\sum_{i=1}^{n}\left(\sqrt{Q_{o b s, i}}-\sqrt{\bar{Q}_{o b s}}\right)^{2}}
$$

184 where, $Q_{\text {pred,i }}$ and $Q_{o b s, i}$ are the predicted and observed streamflow values $\left(\mathrm{L} \mathrm{T}^{-1}\right)$ on the $i^{\text {th }}$ day

185 respectively, $\bar{Q}_{o b s}$ is the mean of all observed streamflow values $\left(\mathrm{L} \mathrm{T}^{-1}\right)$, and $n$ is the total 186 number of days in the time series. We also use the water balance error (WBE) metric, in 187 addition to NS, for the evaluation of model performance:

$$
W B E=\frac{\sum_{i=1}^{n} Q_{\text {pred }, i}-\sum_{i=1}^{n} Q_{o b s, i}}{\sum_{i=1}^{n} Q_{o b s, i}} \times 100
$$

189 Following Das et al. [2008], the measure of model performance at a given catchment is obtained 190 as an average of NS (and WBE) values from the calibration and validation model runs. The

191 same calibration procedure is used for both lumped and distributed versions of the model.

\section{$192 \quad 3.2 \quad$ Spatially lumped and spatially distributed model configuration}

193 Each catchment is considered as a single areal unit for the lumped model and as a

194 collection of multiple smaller areal units for the distributed model. Following Wigington et al.

195 [2013], the smaller areal units within each catchment (henceforth referred to as landscape units)

196 are delineated as first order sub-watersheds and incremental watersheds (Figure 3). For each

197 catchment, we first extract the stream network from the USGS National Elevation Dataset's 30

198 m DEM using a $25 \mathrm{~km}^{2}$ minimum drainage area threshold for channel initiation. Landscape

199 units are then delineated such that each unit consists of a single stream channel and a

200 contributing local hillslope. As such, the landscape units developed here are analogous to the 
201 Representative Elementary Watersheds (REWs) of Reggiani et al. [1999] or the assessment units 202 of Wigington et al. [2013].

203 For the lumped model, the daily precipitation and air temperature time series are obtained 204 by calculating an areal average of the values from meteorological grids that are either fully or 205 partially located within the catchment's drainage area. For the distributed model, the above 206 procedure is repeated at each individual landscape unit to obtain the spatially variable 207 precipitation and air temperature data in each catchment. Thus, if a particular catchment has 20 208 landscape units, then 20 distinct sets of the meteorological input data are created. To obtain 209 simulated stream flows, the lumped model is run in its original configuration with one210 dimensional meteorological input data [Patil and Stieglitz, 2014]. For the distributed 211 configuration, the EXP-HYDRO model is first run independently at each landscape unit (with 212 local meteorological input data). The streamflow output from all landscape units is then 213 aggregated to obtain catchment streamflow using the following formula:

$$
q_{\text {catchment }}=\frac{\sum_{i=1}^{N} q_{i} \cdot A_{i}}{\sum_{i=1}^{N} A_{i}}
$$

215 where, $q_{\text {catchment }}$ is the streamflow at catchment outlet $\left(\mathrm{L} \mathrm{T}^{-1}\right), N$ is the total number of landscape

216 units within the catchment, and $q_{i}$ and $A_{i}$ are the streamflow $\left(\mathrm{L} \mathrm{T}^{-1}\right)$ and drainage area $\left(\mathrm{L}^{2}\right)$

217 respectively of landscape unit $i(i=1,2, \ldots, N)$. It is important to note the following two 218 assumptions that are made in the distributed model: (1) channel network routing is ignored, i.e., 219 the runoff generated from a landscape unit is assumed to reach the catchment outlet on the same 220 day, and (2) all six calibration parameters of the EXP-HYDRO model are assumed to be same in 221 every landscape unit within the catchment. Thus, the distributed EXP-HYDRO model presented 
222 here is essentially the same as its lumped counterpart; the only difference being the spatially

223 distributed meteorological inputs. Moreover, since the lumped and distributed models are

224 calibrated separately at each catchment, the optimal parameter values are likely to be different

225 for either configuration.

226

227

228

229

230

231

232

233

$$
I_{f}=\left\{\begin{array}{cl}
1-P E T / P, & \text { if } \quad P>P E T \\
0, & \text { if } \quad P=P E T \\
P / P E T-1, & \text { if } \quad P<P E T
\end{array}\right.
$$

234 where, $I_{f}$ is the Feddema moisture index whose values vary between -1 and 1 , and $P$ and PET

235 are the mean annual precipitation and potential evapotranspiration respectively (derived from the

236 long-term data of Climate Source, Inc.; see Section 2). Following Wigington et al. [2013], we

237 calculate the $I_{f}$ values of each landscape unit and classify the units into one of the following six

238 moisture classes: "V" (very wet, $I_{f} \geq 0.66$ ), "W" (wet, $0.66>I_{f} \geq 0.33$ ), "M" (moist,

$2390.33>I_{f} \geq 0$ ), "D" (dry, $0>I_{f} \geq-0.33$ ), "S" (semi-arid, $-0.33>I_{f} \geq-0.66$ ), and "A" (arid,

$\left.240-0.66>I_{f}\right)$. The moisture homogeneity index $I_{M}$ is then calculated as the percent areal

241 coverage of the moisture class that has the maximum amount of area within the catchment.

242 Thus, if a given catchment has completely homogeneous climate, all landscape units in that 
243 catchment will belong to the same moisture class and the catchment will have an $I_{M}$ value of

$244100 \%$. Any value of $I_{M}$ that is less than $100 \%$ is indicative of spatial variability of moisture

245 within the catchment.

246 For the temperature variability index $\left(I_{T V}\right)$, we first obtain the mean annual temperature

$247 T$ for each landscape unit (derived from the long-term data of Climate Source, Inc.; see Section

248 2). $I_{T V}$ (unit: ${ }^{\circ} \mathrm{C}$ ) is then calculated for each catchment with the following formula:

$$
I_{T V}=\max \left(T_{1}, T_{2}, \ldots, T_{N}\right)-\min \left(T_{1}, T_{2}, \ldots, T_{N}\right)
$$

250 where, $N$ is the total number of landscape units within the catchment.

\section{Results}

253 We first analyze the differences in simulation performance between the lumped and

254 distributed versions of the EXP-HYDRO model at all 41 study catchments. Figure 4a shows a

255 1:1 comparison of the NS values obtained with the lumped and distributed models. In most

256 catchments (38 out of 41) the distributed model has improved NS values than the lumped model,

257 although for 25 catchments the improvement is modest $(<10 \%)$. NS values for the lumped

258 model vary from 0.29 to 0.94 , with a median value of 0.70 . On the other hand, NS values for the

259 distributed model vary from 0.32 to 0.94 , with a median value of 0.79 . The percentage

260 improvement in NS values with the distributed model ranges from $-0.12 \%$ to $49.67 \%$, with a

261 median improvement of $6.63 \%$. Out of the 41 catchments in total, 13 catchments show NS

262 improvement of greater than $10 \%$ with the distributed model. There are only three catchments

263 for which the distributed model has lower NS values than the lumped model, but with very small

264 amounts of deterioration $(-0.12 \%,-0.11 \%$, and $-0.03 \%)$. Figure $4 \mathrm{~b}$ shows a $1: 1$ comparison of

265 the WBE values obtained with the lumped and distributed models. For the majority of 
catchments (with the exception of two outliers), the WBE values are located close to, and

267 scattered on both sides of, the 1:1 line. The two outlier catchments in Figure $4 \mathrm{~b}$ are located in

268 the eastern drier region of Oregon. Both lumped and distributed models perform poorly at these

269 catchments (NS < 0.4). Therefore, we suspect that the big deviation of WBE values might be

270 arising from poor parameter identification at these catchments, rather than any physical reason.

271 The overall results from Figure 4 suggest that, unlike NS, there appears to be no systematic

272 difference between the lumped and distributed model in terms of the WBE metric.

273 Next, we examine the improvement in model performance achieved by the distributed

274 model within the context of long-term spatial climate variability in a catchment. For the purpose

275 of this analysis, we define model performance improvement as the \% improvement in NS

276 obtained with the distributed model at each catchment. The two metrics of spatial climate

277 variability, $I_{M}$ and $I_{T V}$, show considerable range among our study catchments. $I_{M}$ varies from

$27838.1 \%$ to $100 \%$, with a median value of $78.7 \%$; whereas $I_{T V}$ varies from $0.7{ }^{\circ} \mathrm{C}$ to $8.1{ }^{\circ} \mathrm{C}$, with a

279 median value of $3.5^{\circ} \mathrm{C}$. Figures $5 \mathrm{a}$ and $5 \mathrm{~b}$ show the relationship of $\%$ NS improvement with $I_{M}$

280 and $I_{T V}$, respectively. Both these relationships are also fit with a non-linear quadratic model to

281 determine how much of the variance in \% NS improvement can be explained by each metric.

282 High performance improvement is observed for catchments with low $I_{M}$ values (i.e., low

283 homogeneity of moisture distribution), and the amount of improvement declines with increasing

$284 I_{M}$ value (Figure 5a). However, this declining pattern is observed only among catchments with

285 relatively low moisture homogeneity $\left(I_{M}<80 \%\right)$. The relationship between $\%$ NS improvement

286 and $I_{M}$ becomes scattered for the more homogeneous catchments $\left(I_{M}>80 \%\right)$. The highest

287 variability of \% NS improvement is observed in completely homogeneous catchments ( 
$288 I_{M}=100 \%$ ). For the metric $I_{T V}$, greater improvement in model performance is observed for

289 higher $I_{T V}$ values (Figure 5b). Nonetheless, the relationship shows a high degree of scatter,

290 especially for higher values of $I_{T V} \cdot \mathrm{R}^{2}$ value of the non-linear quadratic fit (red dashed line in

291 Figures 5a and 5b) is 0.25 for the relationship of \% NS improvement with $I_{M}$ and 0.36 for the 292 relationship of \% NS improvement with $I_{T V}$.

293 Since Figure 5a shows a noticeably different behavior for catchments with $I_{M}<80 \%$

294 than for those with $I_{M}>80 \%$, we segregate them into two distinct groups, henceforth referred to 295 as Group $1\left(I_{M}<80 \%, \mathrm{n}=21\right)$ and Group $2\left(I_{M}>80 \%, \mathrm{n}=20\right)$ catchments. Figure 6 shows

296 the location of both Group 1 and Group 2 catchments. Group 1 catchments are mostly located in 297 the central drier parts of the PNW; although there are a few along the Oregon Coast range and 298 the Rocky Mountains. Most of the Group 2 catchments are located in the wetter parts of the 299 PNW, along the western sides of the Cascade and Rocky Mountain ranges; a few are located 300 along the coastal mountains near the Pacific coast. Mean annual precipitation varies from 540 $301 \mathrm{~mm}$ to $2340 \mathrm{~mm}$ (median $=935 \mathrm{~mm}$ ) in Group 1 catchments, and from $812 \mathrm{~mm}$ to $3615 \mathrm{~mm}$ 302 (median $=1690 \mathrm{~mm}$ ) in Group 2 catchments. We further examine the relationships of $\% \mathrm{NS}$ 303 improvement with $I_{M}$ and $I_{T V}$ separately for each group. Figures $7 \mathrm{a}$ and $7 \mathrm{~b}$ show the 304 relationship of \% NS improvement with $I_{M}$ and $I_{T V}$ respectively for the Group 1 catchments. A 305 distinct and inversely proportional relationship is observed between \% NS improvement and $I_{M}$ $306\left(R^{2}=0.46\right)$. On the other hand, a directly proportional but weaker $\left(R^{2}=0.21\right)$ relationship is 307 observed between \% NS improvement and $I_{T V}$. In sharp contrast, for Group 2 catchments 308 (Figures 7c and 7d), we find that virtually no relationship exists between \% NS improvement and 
$309 I_{M}\left(\mathrm{R}^{2}=0.04\right)$, whereas a strong non-linearly increasing relationship $\left(\mathrm{R}^{2}=0.70\right)$ exists between

$310 \%$ NS improvement and $I_{T V}$.

\section{Discussion}

313 Results show that the distributed version of EXP-HYDRO model performs better than its

314 lumped counterpart in 38 out of 41 catchments, and noticeably better (>10\% NS improvement)

315 in 13 out of 41 catchments. This finding clearly demonstrates the importance of incorporating

316 spatially distributed meteorological inputs into hydrologic models, at least for certain types of

317 catchments. In a study similar to ours, Vaze et al. [2011] compared the lumped and distributed

318 versions of four hydrologic models at 240 catchments in southeast Australia. Contrary to our

319 results, they found that only marginal improvement occurred with distributed models, and most

320 of it in larger catchments $\left(>1000 \mathrm{~km}^{2}\right)$. However, Vaze et al. [2011] did not simulate snow

321 processes in their hydrologic models, and they also did not quantify the spatial climate variability

322 in their study catchments. Figure 8 shows the relationship of drainage area and \% NS

323 improvement for our study catchments. This relationship is highly scattered and exhibits no

324 particular trend, which suggests that drainage area does not necessarily inform us about spatial

325 climate variability within a catchment.

326 Within the context of the PNW region (Figure 6), the two metrics of spatial climate

327 variability seem to provide complementary information. Specifically, the moisture homogeneity

328 index $\left(I_{M}\right)$ represents the spatial variability of wetness, i.e., the competition of precipitation

329 input and evaporative demand, in a catchment. On the other hand, the temperature variability

330 index $\left(I_{T V}\right)$ appears to represent the spatial variability of precipitation phase (rain vs. snow) in a

331 catchment. Figure 9 shows the relationship between $I_{T V}$ and the lowest observed mean annual 
332 temperature (amongst all landscape units) within a catchment. This relationship has a significant

333 declining trend $\left(\mathrm{R}^{2}=0.59, \mathrm{p}<0.01\right)$, and shows that catchments with high $I_{T V}$ values tend to

334 have very low (near or below freezing) values of mean annual temperature in their coldest

335 landscape unit. This suggests that catchments with high $I_{T V}$ values (i.e., high temperature

336 variability) are also likely to have high spatial variability of precipitation phase. Interestingly,

337 results show that neither $I_{M}$ nor $I_{T V}$ alone is sufficient to explain whether a particular catchment

338 will benefit from the use of a distributed model (Figures 5a and 5b). However, the combined use

339 of both these metrics provides a much better understanding of the types of catchments for which

340 the distributed model provides better streamflow predictions. A logical expectation would be

341 that catchments with low moisture homogeneity (low $I_{M}$ ) will have the largest $\%$ NS

342 improvement, and this improvement will reduce as we move towards catchments with more

343 homogeneous moisture distribution (high $I_{M}$ ). We do observe this trend, but only among the

344 Group 1 catchments (Figure 7a). Moreover, compared to $I_{M}, I_{T V}$ has a weaker relationship

345 with \% NS improvement for Group 1 catchments (Figure 7b). This suggests that for catchments

346 with relatively low moisture homogeneity, the spatial variability of wetness is a better indicator

347 of performance improvement with a distributed model than the spatial variability of precipitation

348 phase. A completely opposite behavior is observed for Group 2 catchments $\left(I_{M}>80 \%\right)$. For

349 these catchments, $I_{M}$ has virtually no explanatory power of $\%$ NS improvement (Figure 7c),

350 whereas $I_{T V}$ has a substantially higher explanatory power (Figure 7d). This suggests that for

351 catchments with high moisture homogeneity, the spatial variability of precipitation phase is a

352 better indicator of performance improvement with a distributed model than the spatial variability 353 of wetness. 
Figure 10 shows the thirteen catchments for which more than $10 \%$ NS improvement is

355 obtained with the distributed model. Of these, the seven Group 2 catchments with high wetness

356 homogeneity are located in wetter regions of the PNW (Olympic Peninsula, and the western

357 flanks of the Cascade and Rocky Mountains) where all parts of the catchment receive high

358 amounts of precipitation. However, the steep elevation gradients in these regions create

359 substantial spatial variability in air temperature [Jefferson, 2011; Leibowitz et al., 2012; Nolin

360 and Daly, 2006]. This is reflected in the high $I_{T V}$ values observed at most of these catchments

361 (Figure 7d). While spatially uniform meteorological inputs might provide good enough estimate

362 of precipitation amount in some cases, they are likely to miss the spatial variability of

363 precipitation phase. Use of lumped models in such catchments can lead to erroneous estimation

364 of the amount of snow accumulation and the timing of snowmelt. Thus, a spatially distributed

365 representation of meteorological inputs appears to be important in catchments where

366 heterogeneous precipitation phase is a significant factor (even if the same amount of

367 precipitation occurs in the rain and snow dominated areas). Capturing the spatial variability of

368 precipitation phase is even more critical in the wet mountainous areas of the PNW because most

369 climate change projections forecast a high vulnerability to the amount and the extent of snow

370 accumulation in those parts [Nolin and Daly, 2006; Regonda et al., 2005; Salathé et al., 2008;

371 Sproles et al., 2013]. It is worth mentioning here that several hydrologic modeling studies have

372 also accounted for spatially variable precipitation phase by discretizing catchments in the vertical

373 dimension based on elevation bands [Abdulla and Lettenmaier, 1997; Hartman et al., 1999;

374 Parajka and Blöschl, 2008]. Although beyond the scope of our study, it would be interesting to

375 compare how well the spatial variability of climate is represented when a catchment is

376 discretized in the vertical dimension (elevation bands) instead of horizontal dimension (sub- 
377 catchments). The six Group 1 catchments in Figure 10 are located in the drier central parts of the

378 PNW. Catchments in this region typically contain rivers that are fed by a smaller headwater area

379 that receives most of the precipitation and flow downstream into a larger semi-arid landscape

380 [Wigington et al., 2013]. Distributed models have an obvious advantage in these catchments

381 because a lumped representation of the meteorological inputs is likely to misestimate both

382 precipitation phase and magnitude.

383 A number of assumptions and simplifications were made in our methods that could

384 potentially influence the findings of this study. For the distributed EXP-HYDRO model, we

385 used the same parameter values in all landscape units. This simplification essentially ignores the

386 spatial variability of catchment properties such as land use, geology, and soil type, which can

387 play an important role in the filtering of spatially variable rainfall input. Numerous studies with

388 event scale hydrologic models have shown that a catchment's ability to dampen the rainfall

389 signal is an important indicator of whether a distributed model will perform better during a

390 spatially variable rainfall event [Arnaud et al., 2002; Obled et al., 1994; Segond et al., 2007;

391 Smith et al., 2004]. It is not clear though whether (and how) the heterogeneous catchment

392 properties will dampen the effects of spatially variable meteorological inputs for continuous

393 streamflow prediction. We also ignored channel network routing for the distributed EXP-

394 HYDRO model. The assumption here was that the runoff generated from all landscape units

395 reaches the catchment outlet on the same day. While we did choose catchments within a limited

396 range of drainage area $\left(500 \mathrm{~km}^{2}\right.$ to $\left.5000 \mathrm{~km}^{2}\right)$ to mitigate the effects of this assumption, it is

397 possible that some catchments might benefit more than others by the use of distributed model

398 with explicit channel network routing. We used a gridded meteorological dataset [Maurer et al.,

399 2002] to generate both the lumped and distributed inputs for all catchments. The spatial 
400 resolution and quality of this dataset has a huge influence on how well we can characterize the 401 spatial variability of meteorological inputs in our catchments. While the Maurer et al. [2002]

402 data has been used extensively in many hydrologic studies, it must be acknowledged that

403 precipitation estimates are usually poorer at high elevations and in regions with fewer

404 meteorological stations. The choice of using two specific climate variability metrics $\left(I_{M}\right.$ and

$405 I_{T V}$ ) also influenced the way in which our results were interpreted. For $I_{M}$, we were in many 406 ways building on the hydrologic classification work of Wigington et al. [2013] and chose the 407 areal dominance concept (of climate class) as a measure of homogeneity. Alternate metrics such 408 as Shannon's diversity index [Shannon, 1948] or the standard deviation of $I_{f}$ could have served 409 a similar function, but we chose $I_{M}$ due to the high physical realism of its numerical values. For $410 I_{T V}$, our goal was to highlight the maximum extent of the spatial temperature contrast within 411 each catchment; especially because high elevation gradients in some parts the PNW create 412 distinct elevation divides for snow vs. rain type precipitation in the winter months. Alternate 413 metrics such as the standard deviation of air temperature could have also provided a function 414 similar to $I_{T V}$. We only used one type of model structure (EXP-HYDRO) to test the effects of 415 lumped and distributed meteorological inputs. While the use of a different model might provide 416 different quality of simulation performance, we think that similar findings (as of our study) are 417 likely to be obtained by using other commonly used hydrologic models. Moreover, studies with 418 multi-model assessments over a large number of catchments have shown that the geographic 419 patterns of hydrologic predictability tend to be more or less similar for models that include the 420 same hydrological processes [Oudin et al., 2008; Vaze et al., 2011]. 
In this paper, we compared the streamflow simulation performance of lumped and

424 distributed versions of the EXP-HYDRO model at 41 catchments in the Pacific Northwest region

425 of USA. Results showed that the distributed model performs better than the lumped model in

426 most (38 out of 41) catchments. Performance improvement using the distributed model (in

427 comparison to the lumped model) was further analyzed with respect to two metrics of spatial

428 climate variability in a catchment, viz., moisture homogeneity index $\left(I_{M}\right)$ and temperature

429 variability index $\left(I_{T V}\right)$. We found that for catchments with low moisture homogeneity (

$\left.430 I_{M}<80 \%\right), I_{M}$ was a better predictor of model performance improvement than $I_{T V}$. Such

431 catchments are more likely to be located in dry regions with small headwater areas that supply

432 most of the water. A completely opposite trend was observed among catchments with high

433 moisture homogeneity $\left(I_{M}>80 \%\right.$ ), most of which were located in the wetter areas of the PNW.

434 Based on the results presented this study, we conclude that the use of spatially distributed

435 meteorological inputs in hydrologic models has the potential to substantially improve streamflow

436 predictions, at least for certain types of catchments. Catchments with highly variable moisture

437 distribution are the obvious candidates for using spatially distributed meteorological inputs in a

438 hydrologic model. On the other hand, homogeneously wet catchments can greatly benefit from

439 spatially distributed meteorological inputs if there is high spatial variability of precipitation

440 phase. Our assumption of spatially uniform model parameter values within a catchment ensured

441 that any improvement obtained with the distributed model was solely based on the spatially

442 distributed representation of meteorological inputs. However, this assumption will have to be

443 relaxed for future investigations of the effects of spatially variable land use, soil types, and/or

444 geology on catchment streamflow predictions. 


\section{Acknowledgements}

447 We are thankful to J. Renée Brooks, Stacey Archfield, Marc Stieglitz, and two anonymous 448 reviewers for valuable comments and suggestions that have greatly improved the paper. The 449 first (Patil) and the fourth (Sproles) authors were supported by ORISE postdoctoral fellowship 450 for the duration of this study. The information in this document has been funded entirely by the

451 U.S. Environmental Protection Agency. This manuscript has been subjected to Agency review 452 and has been approved for publication. Mention of trade names or commercial products does not 453 constitute endorsement or recommendation for use.

\section{References}

456 Abdulla, F. A., and D. P. Lettenmaier (1997), Development of regional parameter estimation 457 equations for a macroscale hydrologic model, Journal of Hydrology, 197(1-4), 230-257, 458 doi: 10.1016/s0022-1694(96)03262-3.

459 Andréassian, V., C. Perrin, C. Michel, I. Usart-Sanchez, and J. Lavabre (2001), Impact of 460 imperfect rainfall knowledge on the efficiency and the parameters of watershed models, Journal of Hydrology, 250(1-4), 206-223, doi: http://dx.doi.org/10.1016/S0022-

463 Andréassian, V., A. Oddos, C. Michel, F. Anctil, C. Perrin, and C. Loumagne (2004), Impact of 464 spatial aggregation of inputs and parameters on the efficiency of rainfall-runoff models:

465 A theoretical study using chimera watersheds, Water Resources Research, 40(5), 466 W05209, doi: 10.1029/2003wr002854. 
Arnaud, P., C. Bouvier, L. Cisneros, and R. Dominguez (2002), Influence of rainfall spatial variability on flood prediction, Journal of Hydrology, 260(1-4), 216-230, doi: http://dx.doi.org/10.1016/S0022-1694(01)00611-4.

Bárdossy, A., and T. Das (2008), Influence of rainfall observation network on model calibration and application, Hydrology and Earth System Sciences, 12(1), 77-89, doi: 10.5194/hess12-77-2008.

Beven, K. J., and M. J. Kirkby (1979), A physically based, variable contributing area model of basin hydrology / Un modèle à base physique de zone d'appel variable de l'hydrologie du bassin versant, Hydrological Sciences Bulletin, 24(1), 43-69, doi:

$10.1080 / 02626667909491834$.

Beven, K. J., and G. M. Hornberger (1982), Assessing the effect of spatial pattern of precipitation in modeling stream flow hydrographs, JAWRA Journal of the American Water Resources Association, 18(5), 823-829, doi: 10.1111/j.1752-1688.1982.tb00078.x.

Boyle, D. P., H. V. Gupta, S. Sorooshian, V. Koren, Z. Zhang, and M. Smith (2001), Toward improved streamflow forecasts: value of semidistributed modeling, Water Resources Research, 37(11), 2749-2759, doi: 10.1029/2000wr000207.

Brown, D. P., and K. F. Kipfmueller (2011), Pacific Climate Forcing of Multidecadal Springtime Minimum Temperature Variability in the Western United States, Annals of the Association of American Geographers, 102(3), 521-530, doi: 10.1080/00045608.2011.627052.

Cayan, D. R. (1996), Interannual Climate Variability and Snowpack in the Western United States, Journal of Climate, 9(5), 928-948, doi: 10.1175/15200442(1996)009<0928:icvasi>2.0.co;2. 
Chaubey, I., C. T. Haan, J. M. Salisbury, and S. Grunwald (1999), Quantifying model output uncertainty due to spatial variability of rainfall, JAWRA Journal of the American Water Resources Association, 35(5), 1113-1123, doi: 10.1111/j.1752-1688.1999.tb04198.x.

Das, T., A. Bárdossy, E. Zehe, and Y. He (2008), Comparison of conceptual model performance using different representations of spatial variability, Journal of Hydrology, 356(1-2), 106-118, doi: http://dx.doi.org/10.1016/j.jhydrol.2008.04.008.

Falcone, J. A., D. M. Carlisle, D. M. Wolock, and M. R. Meador (2010), GAGES: A stream gage database for evaluating natural and altered flow conditions in the conterminous United States, Ecology, 91(2), 621-621, doi: 10.1890/09-0889.1.

Faurès, J.-M., D. C. Goodrich, D. A. Woolhiser, and S. Sorooshian (1995), Impact of small-scale spatial rainfall variability on runoff modeling, Journal of Hydrology, 173(1-4), 309-326, doi: http://dx.doi.org/10.1016/0022-1694(95)02704-S.

Feddema, J. (2005), A Revised Thornthwaite-Type Global Climate Classification, Physical Geography, 26(6), 442-466, doi: 10.2747/0272-3646.26.6.442.

Hamlet, A. F., and D. P. Lettenmaier (1999), Effects of Climate Change on Hydrology and Water Resources in the Columbia River Basin, JAWRA Journal of the American Water Resources Association, 35(6), 1597-1623, doi: 10.1111/j.1752-1688.1999.tb04240.x.

Hamon, W. R. (1963), Computation of direct runoff amounts from storm rainfall, Int. Assoc. Sci. Hydrol. Publ, 63, 52-62, doi.

Hartman, M. D., J. S. Baron, R. B. Lammers, D. W. Cline, L. E. Band, G. E. Liston, and C. Tague (1999), Simulations of snow distribution and hydrology in a mountain basin, Water Resources Research, 35(5), 1587-1603, doi: 10.1029/1998wr900096. 
512 Jefferson, A. J. (2011), Seasonal versus transient snow and the elevation dependence of climate 513 sensitivity in maritime mountainous regions, Geophysical Research Letters, 38(16),

$514 \quad$ L16402, doi: 10.1029/2011g1048346.

515 Khakbaz, B., B. Imam, K. Hsu, and S. Sorooshian (2012), From lumped to distributed via semidistributed: Calibration strategies for semi-distributed hydrologic models, Journal of Hydrology, 418-419, 61-77, doi: http://dx.doi.org/10.1016/j.jhydrol.2009.02.021.

Koren, V. I., B. D. Finnerty, J. C. Schaake, M. B. Smith, D. J. Seo, and Q. Y. Duan (1999), Scale dependencies of hydrologic models to spatial variability of precipitation, Journal of Hydrology, 217(3-4), 285-302, doi: http://dx.doi.org/10.1016/S0022-1694(98)00231-5.

Krajewski, W. F., V. Lakshmi, K. P. Georgakakos, and S. C. Jain (1991), A Monte Carlo Study of rainfall sampling effect on a distributed catchment model, Water Resources Research, 27(1), 119-128, doi: 10.1029/90wr01977.

524 Leibowitz, S. G., P. J. Wigington Jr, R. L. Comeleo, and J. L. Ebersole (2012), A temperatureprecipitation-based model of thirty-year mean snowpack accumulation and melt in Oregon, USA, Hydrological Processes, 26(5), 741-759, doi: 10.1002/hyp.8176.

Maurer, E. P., A. W. Wood, J. C. Adam, D. P. Lettenmaier, and B. Nijssen (2002), A Long-Term

McMillan, H., B. Jackson, M. Clark, D. Kavetski, and R. Woods (2011), Rainfall uncertainty in Hydrologically Based Dataset of Land Surface Fluxes and States for the Conterminous United States, Journal of Climate, 15(22), 3237-3251, doi: 10.1175/15200442(2002)015<3237:althbd>2.0.co;2. hydrological modelling: An evaluation of multiplicative error models, Journal of Hydrology, 400(1-2), 83-94, doi: http://dx.doi.org/10.1016/j.jhydrol.2011.01.026. 
534 Moulin, L., E. Gaume, and C. Obled (2009), Uncertainties on mean areal precipitation: assessment and impact on streamflow simulations, Hydrology and Earth System Sciences, 13(2), 99-114, doi: 10.5194/hess-13-99-2009.

537

Nicótina, L., E. Alessi Celegon, A. Rinaldo, and M. Marani (2008), On the impact of rainfall patterns on the hydrologic response, Water Resources Research, 44(12), W12401, doi: 10.1029/2007wr006654.

Nolin, A. W., and C. Daly (2006), Mapping “At Risk” Snow in the Pacific Northwest, Journal of Hydrometeorology, 7(5), 1164-1171, doi: 10.1175/jhm543.1.

Obled, C., J. Wendling, and K. Beven (1994), The sensitivity of hydrological models to spatial rainfall patterns: an evaluation using observed data, Journal of Hydrology, 159(1-4), 305-333, doi: http://dx.doi.org/10.1016/0022-1694(94)90263-1.

Oudin, L., C. Perrin, T. Mathevet, V. Andréassian, and C. Michel (2006a), Impact of biased and randomly corrupted inputs on the efficiency and the parameters of watershed models, Journal of Hydrology, 320(1-2), 62-83, doi: http://dx.doi.org/10.1016/j.jhydrol.2005.07.016.

Oudin, L., V. Andréassian, T. Mathevet, C. Perrin, and C. Michel (2006b), Dynamic averaging of rainfall-runoff model simulations from complementary model parameterizations, Water Resources Research, 42(7), W07410, doi: 10.1029/2005wr004636.

Oudin, L., V. Andréassian, C. Perrin, C. Michel, and N. Le Moine (2008), Spatial proximity, physical similarity, regression and ungaged catchments: A comparison of regionalization approaches based on 913 French catchments, Water Resources Research, 44(3), W03413, doi: $10.1029 / 2007 \mathrm{wr} 006240$. 
556 Parajka, J., and G. Blöschl (2008), The value of MODIS snow cover data in validating and calibrating conceptual hydrologic models, Journal of Hydrology, 358(3-4), 240-258, doi: http://dx.doi.org/10.1016/j.jhydrol.2008.06.006.

Patil, S., and M. Stieglitz (2014), Modelling daily streamflow at ungauged catchments: what information is necessary?, Hydrological Processes, 28(3), 1159-1169, doi: 10.1002/hyp.9660.

Patil, S. D., P. J. Wigington Jr, S. G. Leibowitz, and R. L. Comeleo (in press), Use of hydrologic landscape classification to diagnose streamflow predictability in Oregon, JAWRA Journal of the American Water Resources Association, doi: 10.1111/jawr.12143.

Reed, S., V. Koren, M. Smith, Z. Zhang, F. Moreda, D.-J. Seo, and a. Dmip Participants (2004), 4), 27-60, doi: http://dx.doi.org/10.1016/j.jhydrol.2004.03.031.

Refsgaard, J. C., and J. Knudsen (1996), Operational Validation and Intercomparison of Different Types of Hydrological Models, Water Resources Research, 32(7), 2189-2202, doi: 10.1029/96wr00896.

Reggiani, P., S. M. Hassanizadeh, M. Sivapalan, and W. G. Gray (1999), A unifying framework for watershed thermodynamics: constitutive relationships, Advances in Water Resources, 23(1), 15-39, doi: 10.1016/s0309-1708(99)00005-6.

Regonda, S. K., B. Rajagopalan, M. Clark, and J. Pitlick (2005), Seasonal Cycle Shifts in Hydroclimatology over the Western United States, Journal of Climate, 18(2), 372-384, doi: $10.1175 /$ jcli-3272.1. 
577 Safeeq, M., G. E. Grant, S. L. Lewis, and C. L. Tague (2013), Coupling snowpack and 578 groundwater dynamics to interpret historical streamflow trends in the western United 579 States, Hydrological Processes, 27(5), 655-668, doi: 10.1002/hyp.9628.

580 Salathé, E. P., R. Steed, C. F. Mass, and P. H. Zahn (2008), A High-Resolution Climate Model 581 for the U.S. Pacific Northwest: Mesoscale Feedbacks and Local Responses to Climate Change, Journal of Climate, 21(21), 5708-5726, doi: 10.1175/2008jcli2090.1.

Segond, M.-L., H. S. Wheater, and C. Onof (2007), The significance of spatial rainfall representation for flood runoff estimation: A numerical evaluation based on the Lee catchment, UK, Journal of Hydrology, 347(1-2), 116-131, doi: http://dx.doi.org/10.1016/j.jhydrol.2007.09.040.

Shannon, C. E. (1948), A mathematical theory of communication, Bell System Technical Journal, 27, 623-656, doi.

Shen, Z., L. Chen, Q. Liao, R. Liu, and Q. Hong (2012), Impact of spatial rainfall variability on hydrology and nonpoint source pollution modeling, Journal of Hydrology, 472-473(0), 205-215, doi: http://dx.doi.org/10.1016/j.jhydrol.2012.09.019.

Slack, J. R., A. Lumb, and J. M. Landwehr (1993), Hydro-Climatic Data Network (HCDN) Streamflow Data Set, 1874-1988: USGS Water-Resources Investigations Report 93-4076, U.S. Geological Survey, Reston, VA.

Smith, M. B., V. I. Koren, Z. Zhang, S. M. Reed, J.-J. Pan, and F. Moreda (2004), Runoff response to spatial variability in precipitation: an analysis of observed data, Journal of Hydrology, 298(1-4), 267-286, doi: http://dx.doi.org/10.1016/j.jhydrol.2004.03.039. 
Sproles, E., A. Nolin, K. Rittger, and T. Painter (2013), Climate change impacts on maritime mountain snowpack in the Oregon Cascades, Hydrol. Earth Syst. Sci, 17(7), 2581-2597, doi: 10.5194/hess-17-2581-2013.

Thornthwaite, C. W. (1948), An approach toward a rational classification of climate, Geographical review, 38(1), 55-94, doi.

Tobin, C., L. Nicotina, M. B. Parlange, A. Berne, and A. Rinaldo (2011), Improved interpolation of meteorological forcings for hydrologic applications in a Swiss Alpine region, Journal of Hydrology, 401(1-2), 77-89, doi: http://dx.doi.org/10.1016/j.jhydrol.2011.02.010.

Tramblay, Y., C. Bouvier, P. A. Ayral, and A. Marchandise (2011), Impact of rainfall spatial distribution on rainfall-runoff modelling efficiency and initial soil moisture conditions estimation, Nat. Hazards Earth Syst. Sci., 11(1), 157-170, doi: 10.5194/nhess-11-1572011.

Vaché, K. B., and J. J. McDonnell (2006), A process-based rejectionist framework for evaluating catchment runoff model structure, Water Resources Research, 42(2), W02409, doi: $10.1029 / 2005 \mathrm{wr} 004247$.

Vaze, J., D. A. Post, F. H. S. Chiew, J. M. Perraud, J. Teng, and N. R. Viney (2011), Conceptual Rainfall-Runoff Model Performance with Different Spatial Rainfall Inputs, Journal of Hydrometeorology, 12(5), 1100-1112, doi: 10.1175/2011jhm1340.1.

Wigington, P. J., S. G. Leibowitz, R. L. Comeleo, and J. L. Ebersole (2013), Oregon Hydrologic Landscapes: A Classification Framework, JAWRA Journal of the American Water Resources Association, 49(1), 163-182, doi: 10.1111/jawr.12009. 
619 Wilson, C. B., J. B. Valdes, and I. Rodriguez-Iturbe (1979), On the influence of the spatial 620 distribution of rainfall on storm runoff, Water Resources Research, 15(2), 321-328, doi: 10.1029/WR015i002p00321.

622 Zhao, F., L. Zhang, F. H. S. Chiew, J. Vaze, and L. Cheng (2013), The effect of spatial rainfall 623 variability on water balance modelling for south-eastern Australian catchments, Journal 624 of Hydrology, 493(0), 16-29, doi: http://dx.doi.org/10.1016/j.jhydrol.2013.04.028. 


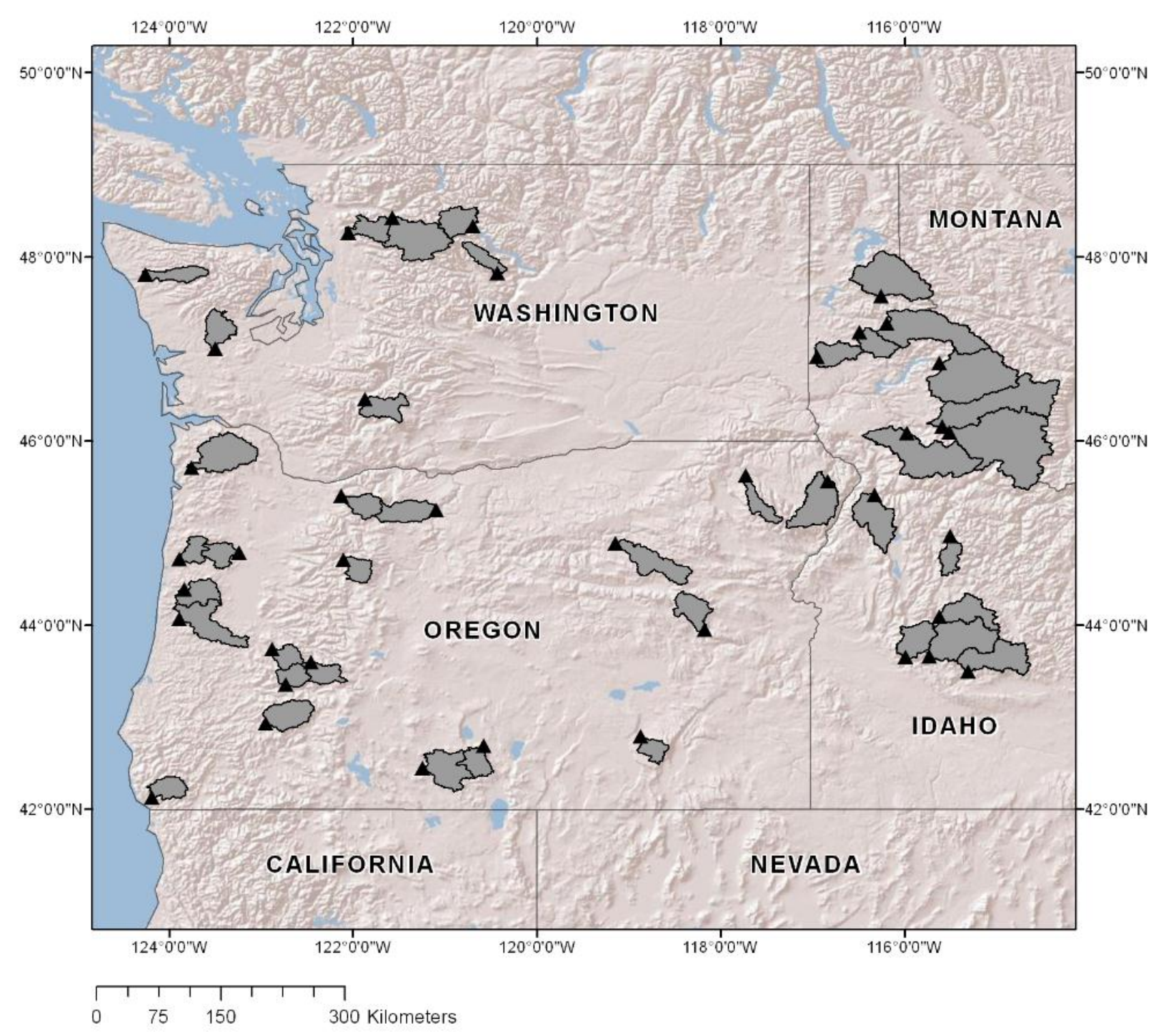

630 Figure 1: Location of the 41 study catchments. Black triangles are the catchment outlets,

631 whereas gray regions are the drainage areas.

632 


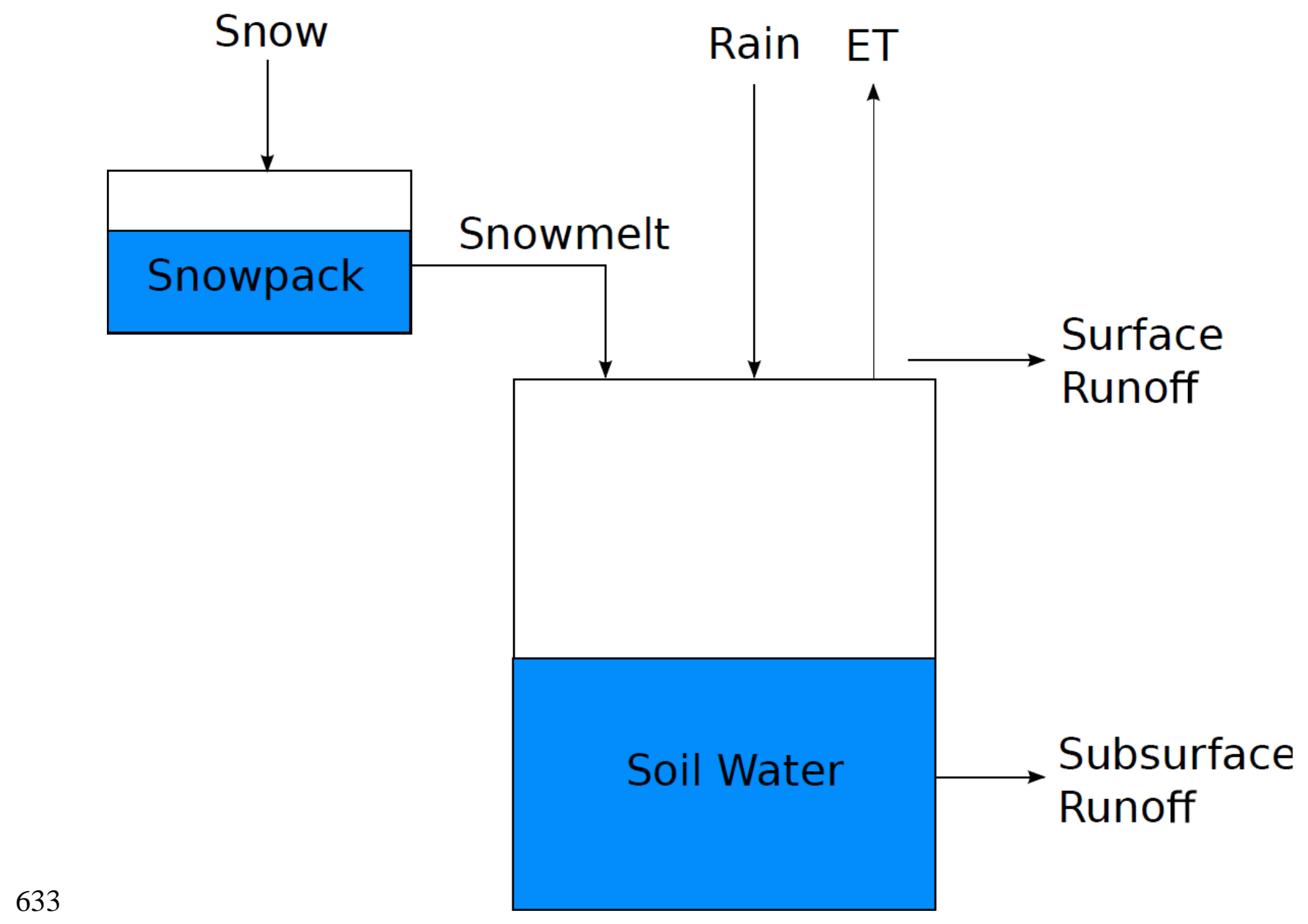

634 Figure 2: Schematic representation of the EXP-HYDRO model.

635 


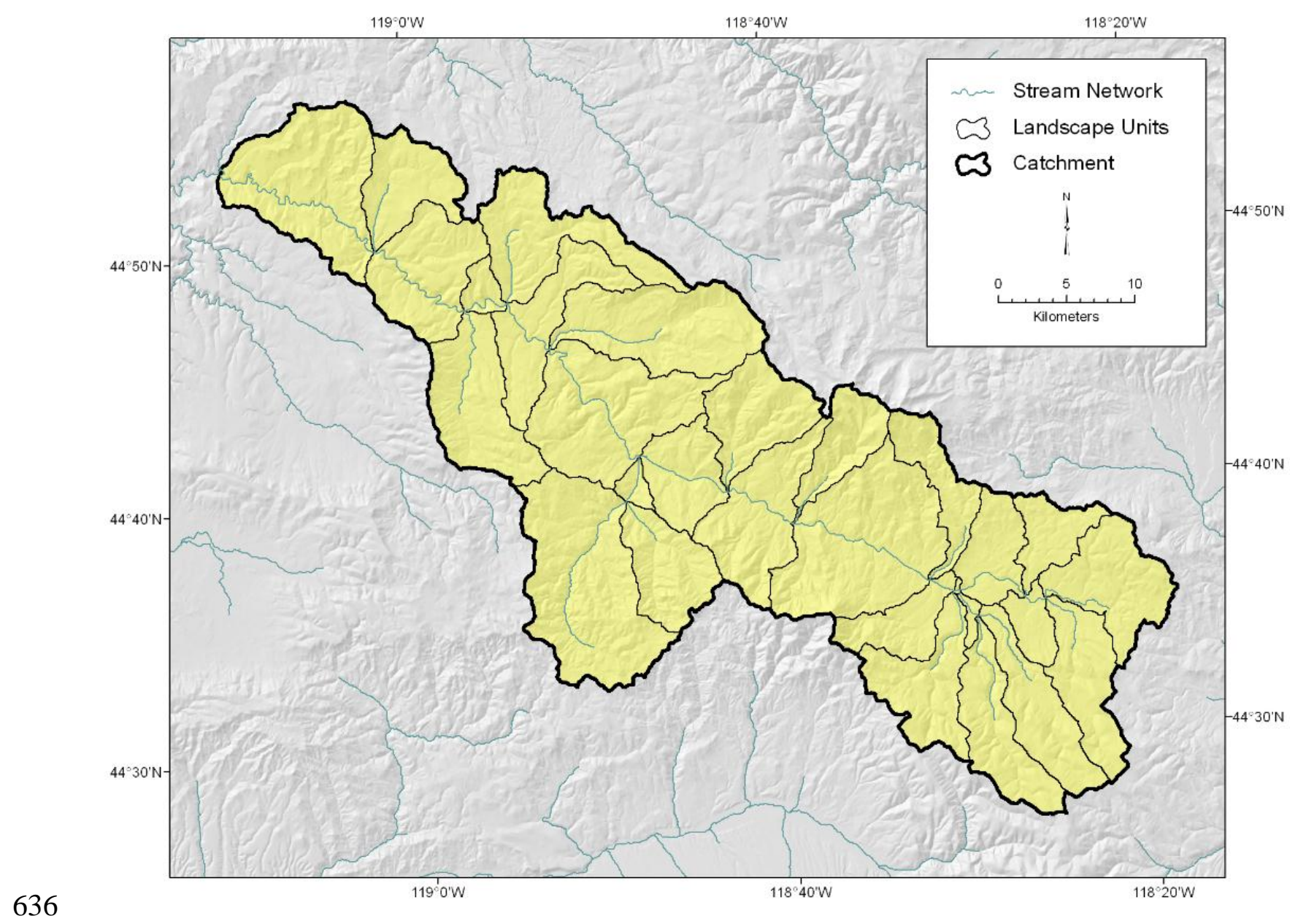

637 Figure 3: Representation of the individual landscape units within a catchment. 
a)

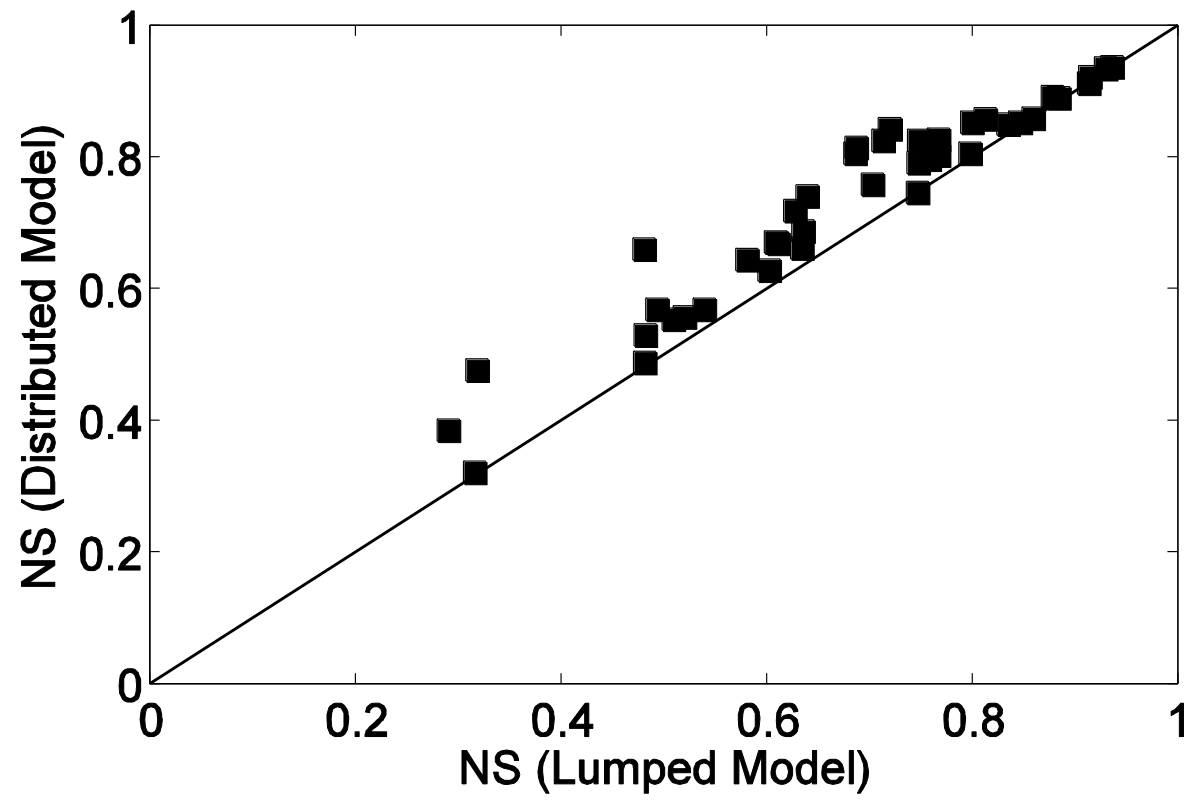

b)

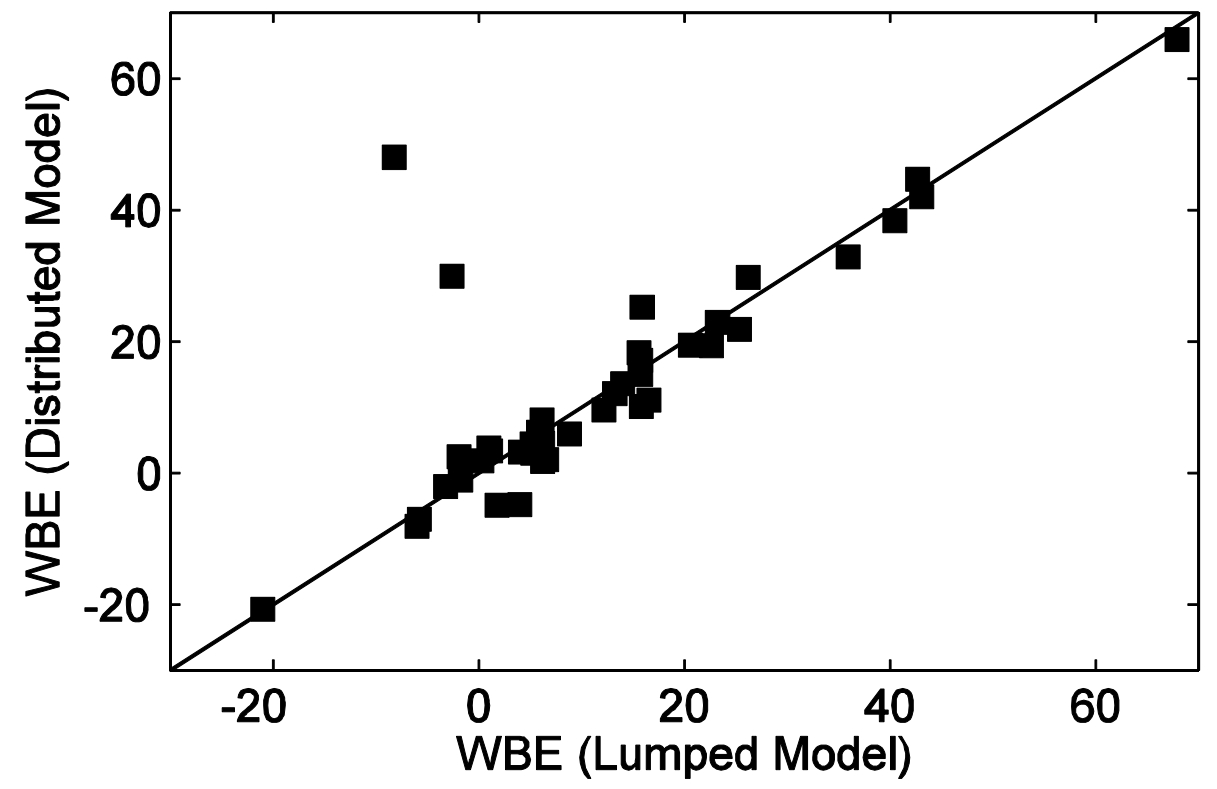

640 Figure 4: A one-on-one comparison between lumped and distributed EXP-HYDRO model with

641 a) Nash-Sutcliffe efficiency (NS), and b) Water Balance Error (WBE). 
a)

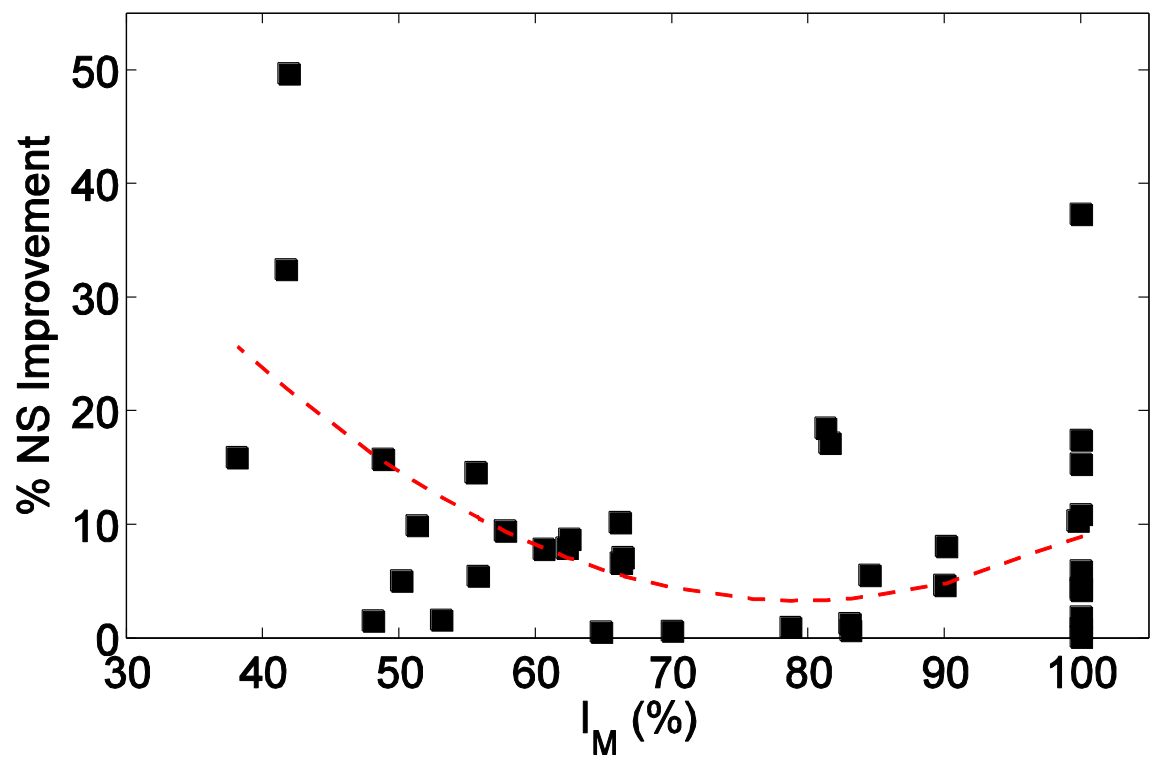

b)

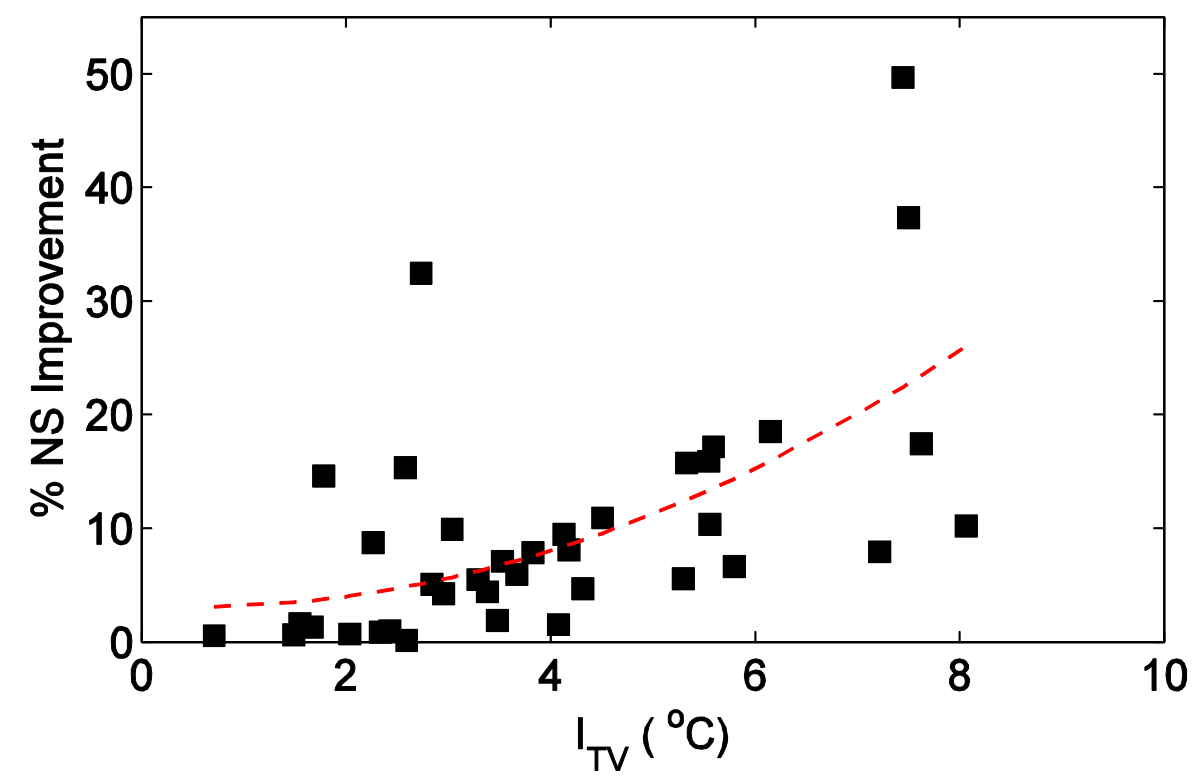

644 Figure 5: Relationship of model performance improvement with a) $I_{M}$, and b) $I_{T V}$. Red 645 dashed line is the regression fit using quadratic equation. 


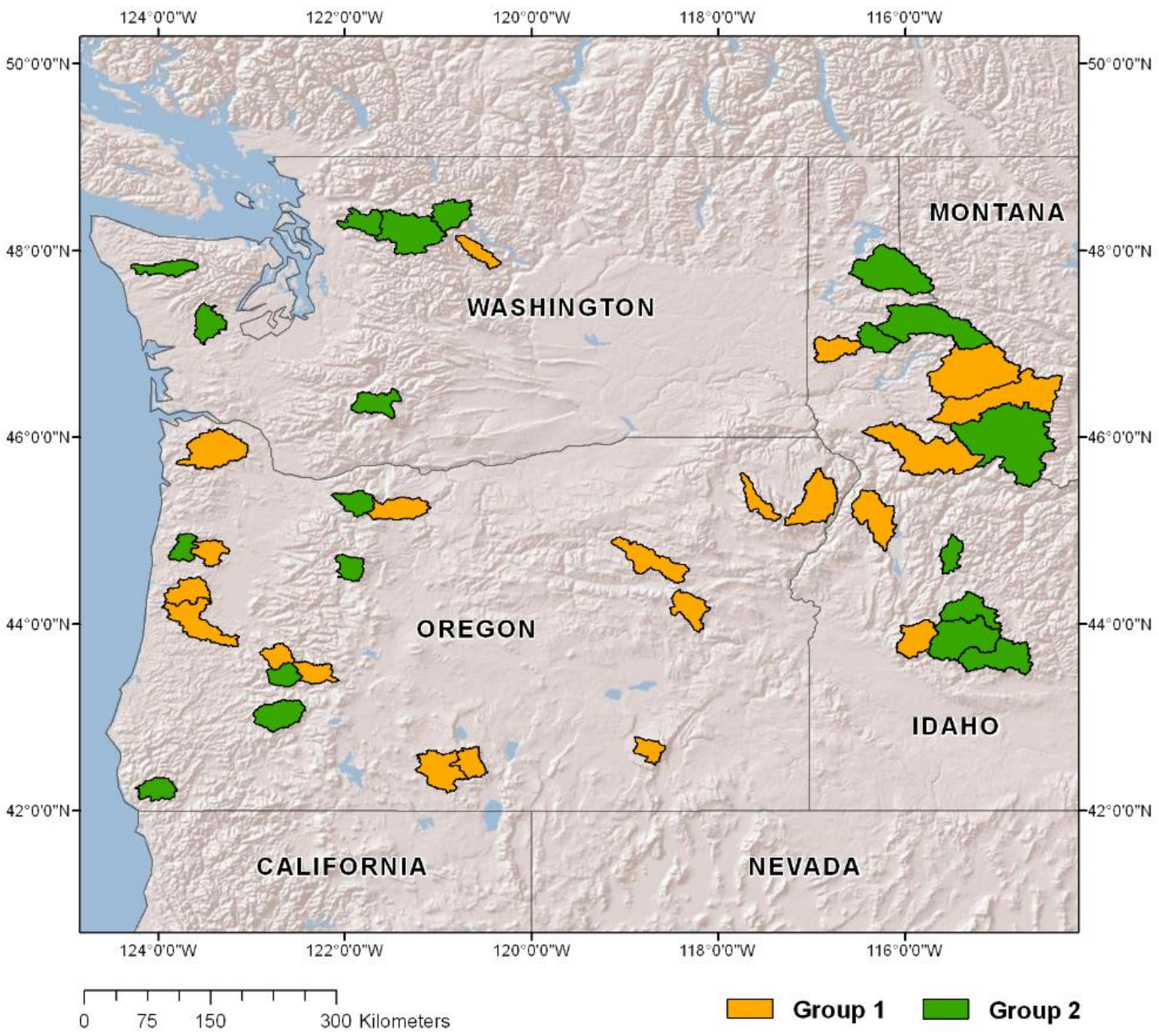

648 Figure 6: Location of the Group $1\left(I_{M}<80 \%\right)$ and Group $2\left(I_{M}>80 \%\right)$ catchments. 
a) Group 1
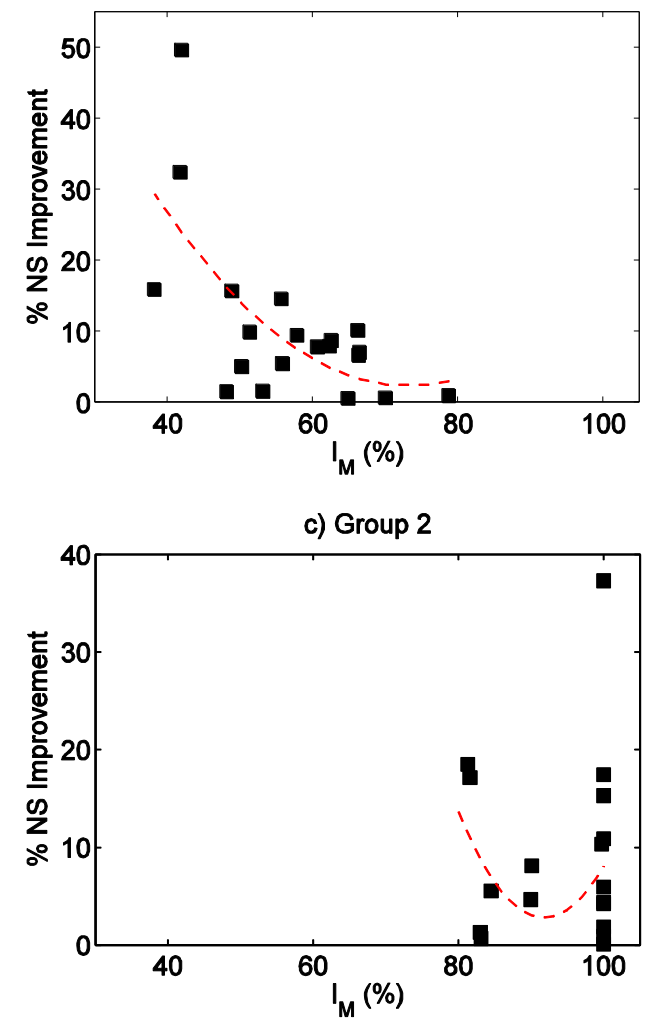

b) Group 1
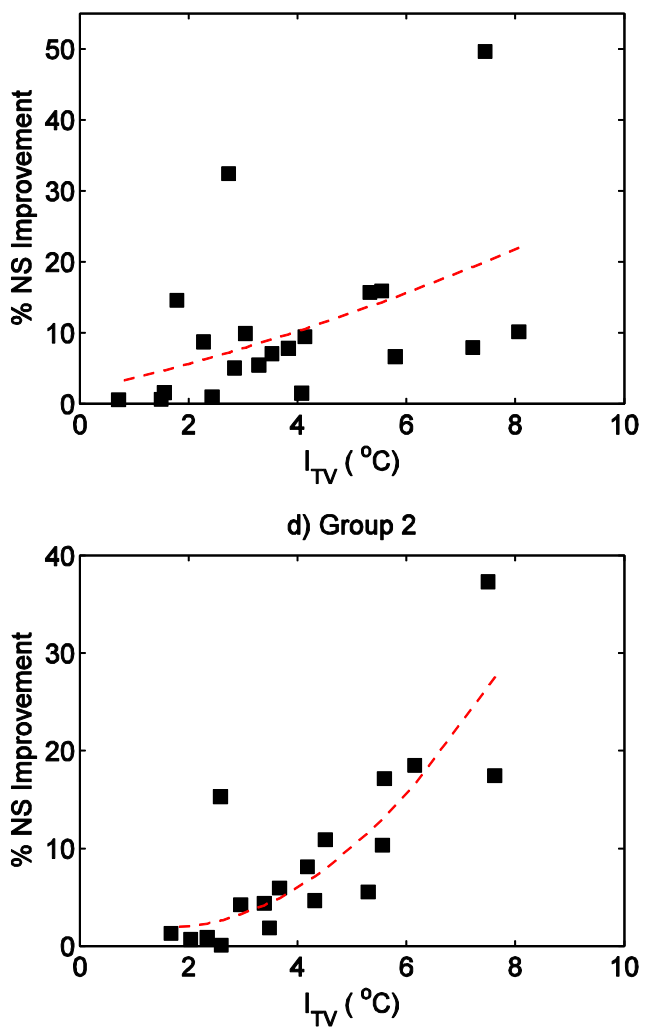

650

651 Figure 7: Relationship of model performance improvement with $I_{M}$ and $I_{T V}$, shown separately

652 for the Group 1 and Group 2 catchments. Red dashed line is the regression fit using quadratic

653 equation.

654 


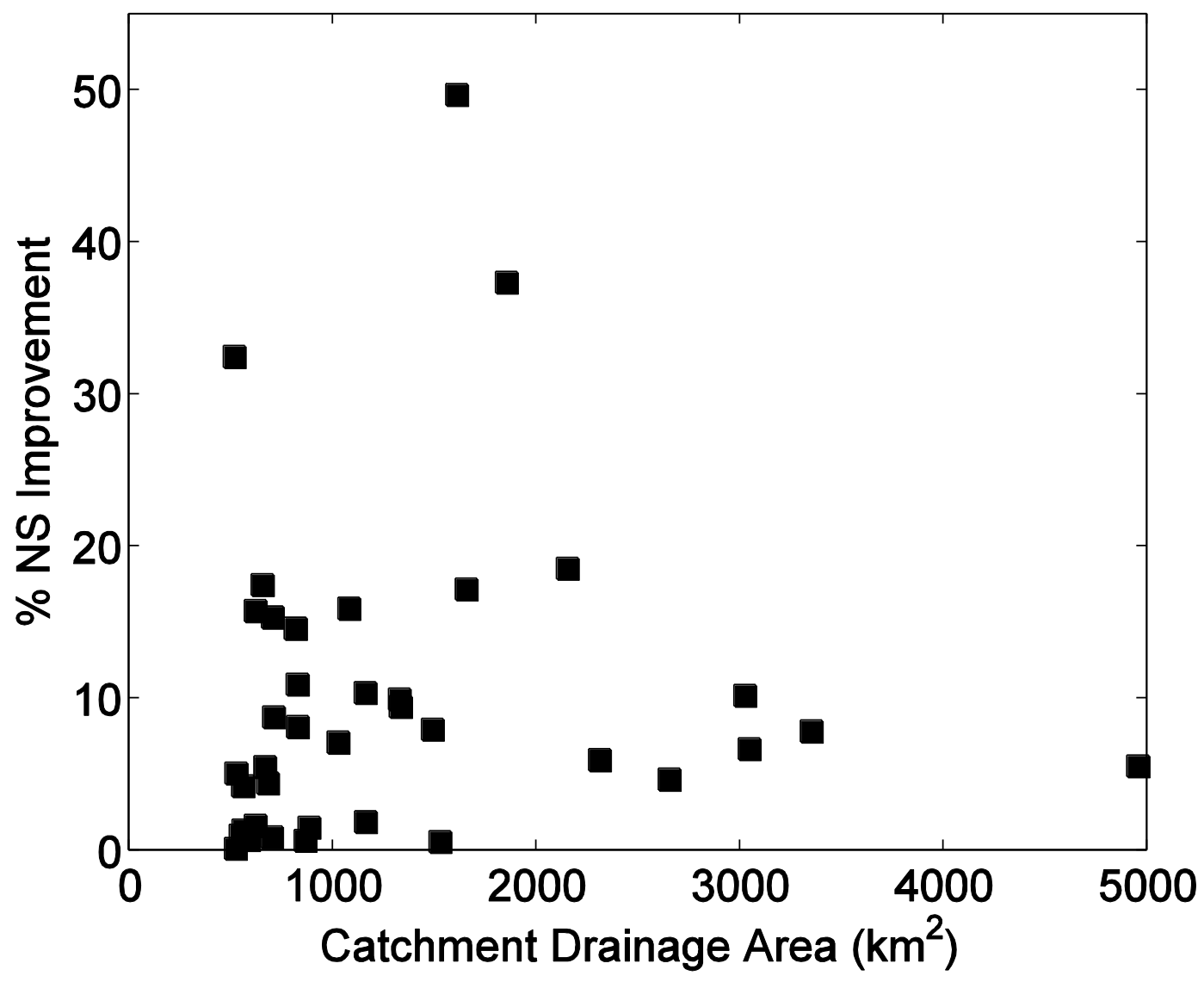

656 Figure 8: Relationship of model performance improvement with catchment drainage area. 657 


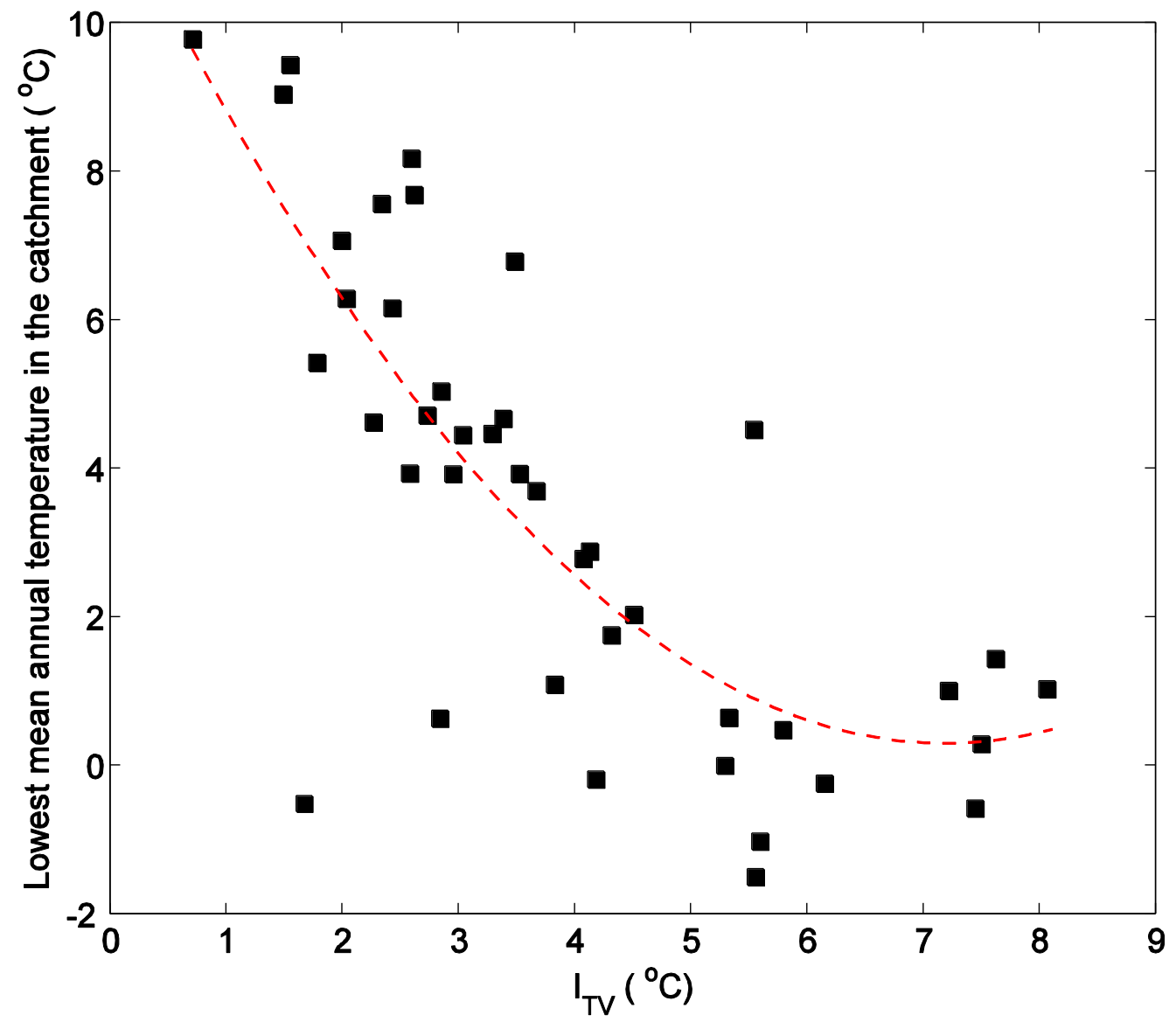

658

659 Figure 9: Relationship between $I_{T V}$ and the lowest mean annual temperature within the

660 catchment. Red dashed line is the regression fit using quadratic equation.

661 


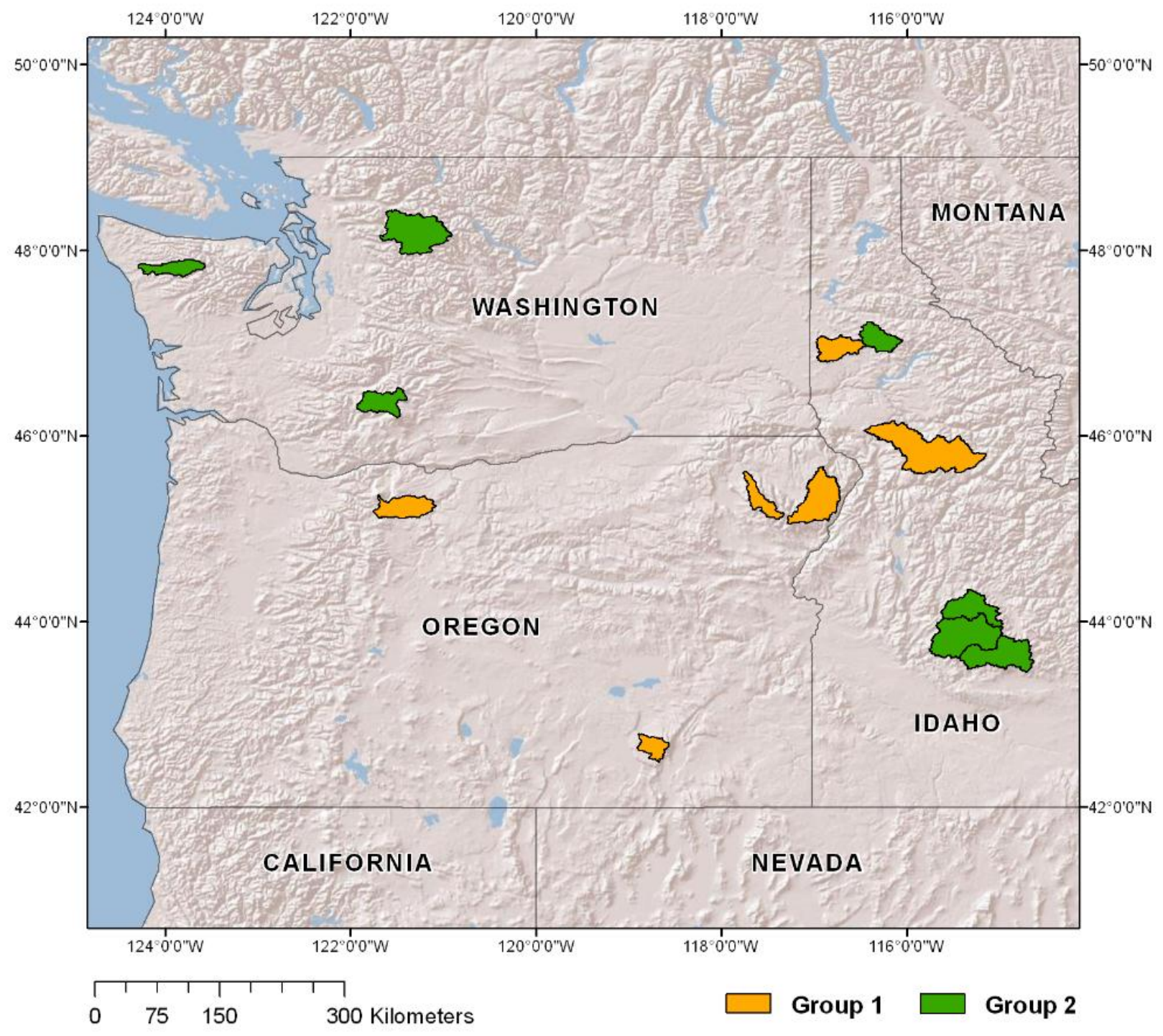

Figure 10: Location of the catchments where distributed model shows more than $10 \%$ NS

664 improvement. Group 1 and Group 2 catchments are shown separately. 